\title{
A New Race of Puccinia helianthi in Sunflower*
}

\author{
Shaw-Ming YANG**
}

\begin{abstract}
A previously unknown race of Puccinia helianthi was isolated from a commercial field of sunflower at Bushland, Texas, in 1984. Sunflower rust differential lines and cultivars that are resistant to the four North American rust races, the ten rust races of Antonelli, and the four rust races of Luciano and Luciani from Argentina were susceptible to this newly isolated race. The five sunflower germplasm lines, HA-R1, HA-R2, HA-R3, HA-R4 and HA-R5 that had been released as resistant to the four North American rust races were also susceptible to this new race. The results showed that this isolate is a new race of the sunflower rust pathogen.
\end{abstract}

(Received November 5, 1985)

Key words : Helianthus annuus, rust.

\section{Introduction}

A new isolate of sunflower rust (Bushland isolate) was collected from cultivated sunflower near Bushland, Texas, in 1984 that was virulent on all three standard Canadian sunflower rust differential lines. Although Saenz pena 74-1-2, one of Antonelli's sunflower rust differential cultivars from Argentina, was resistant to his 10 races in Argentina (E. F. Antonelli, unpublished data), it was susceptible to this new Bushland isolate. Pathogenicity tests were performed with this new rust isolate on the other available sunflower rust differential cultivars and lines and also on the sunflower germplasm lines that were resistant to the four North American (NA) rust races. This paper describes the Bushland isolate as a new race of rust on sunflower.

\section{Materials and Methods}

Sunflower leaves infected with Puccinia helianthi were collected from a commercial sunflower field at Bushland, Texas, in 1984. Single isolated pustules with surrounding leaf tissues were removed and placed on the adaxial surface (pustule in contact with the surface) of cotyledons of sunflower cultivar Saenz pena 74-1-2 at VE stage ${ }^{6}$. A wet cotton plug was placed on top of the tissue. Seedlings were atomized with sterile demineralized water and talc just before inoculation. Pots with the inoculated seedlings were enclosed in plastic bags and incubated in darkness in a growth chamber $(21 \pm 1 \mathrm{C}$ day, $17 \pm 1 \mathrm{C}$

* Contribution from USDA-Agricultural Research Service, P. O. Drawer 10, Bushland, Texas 79012.

** Present Address : USDA-ARS, Conservation and Production Research Laboratory, Bushland, Texas 79012, USA. 
night, $65 \pm 10 \% \mathrm{rh}$ ) for 18 to $22 \mathrm{hr}$. After the pots with inoculated seedlings were removed from the plastic bags, the pots were incubated in the same growth chamber for an additional 11 to 13 days ( $12 \mathrm{hr}$ light). The inoculum was increased also on sunflower line S 37-388.

The cotton plug method ${ }^{2}$ was used to inoculate the sunflower rust differential cultivars, lines, and sunflower germplasm lines. Urediospores produced on Saenz pena 741-2 and S 37-388 were used to inoculate cotyledons and the first pair of true leaves of the seedlings of sunflower rust differentials and sunflower germplasm lines at VE to V2 stages $^{6}$. Small plugs of sterile, wet, absorbent cotton touched to the urediospores on cotyledons or leaves of S $37-388$ or Saenz pena $74-1-2$ were lightly pressed onto the adaxial surface of cotyledons and the first pair of true leaves (one plug per cotyledon or leaf) of the sunflower rust differentials and the germplasm lines. After inoculation, the pot ( $10 \mathrm{~cm}$ in diameter) with the four seedlings (4 seedlings/pot) inoculated with the same isolate was covered with a plastic bag and incubated in darkness in the growth chamber as previously described. The plastic bag was removed after 18 to 22 hours incubation. The inoculated seedlings were then incubated in the same growth chamber (12 hr light) for an additional 11 to 13 days before a reading was taken. Sunflower plants that were inoculated with North American rust races 1, 2, 3 and 4 (T. Gulya, USDA-ARS, Fargo, ND 58105, USA) served as controls. All the differentials and sunflower germplasm lines in Table 1 were inoculated at the same time. This test was repeated three times.

Sackston's ${ }^{4)}$ modified numerical scale was used to rate the reaction types (footnote in Table 1). A direct measurement microscope $(\times 50)$ and transparency chart showing three actual sizes of pustules $(0.2$, 0.4 and $0.6 \mathrm{~mm}$ in diameter) (Fig. 1) were used to characterize the pustules formed on the inoculated cotyledons and leaves of the sunflower rust differentials and the germplasm lines.

Uredia on nine of the differentials and the lines were measured microscopically. Leaves with pustules were detached 14 days post inoculation and floated on FAA solution (Formalin, $13 \mathrm{ml}$; glacial acetic

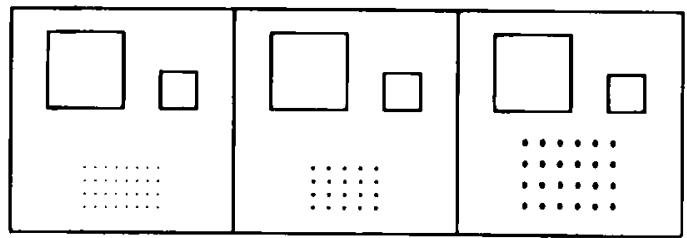

Fig. 1. Actual sizes of black spots in a transparency sheet that was used to compare the size of pustules of Puccinia helianthi on the leaves of sunflower seedlings. Left: $0.2 \mathrm{~mm}$ in diameter; Center : $0.4 \mathrm{~mm}$ in diameter; Right: $0.6 \mathrm{~mm}$ in diameter. Pustules smaller than $0.2 \mathrm{~mm}$ belong to type 1 , and that larger than $0.6 \mathrm{~mm}$ belong to type 4 . The three squares can be used to determine the number of pustules per 9 $\mathrm{cm}^{2}, 1 \mathrm{~cm}^{2}$, and $0.25 \mathrm{~cm}^{2}$, respectively, on the leaves in the field. acid, $5 \mathrm{ml}$; and ethanol, $200 \mathrm{ml}$ ) until the pustules on the adaxial surface were examined under the microscope. The pustules were measured within 3 days. Twenty-five uredia were randomly selected and measured from each half-leaf (fifty in total from each leaf) and two leaves from two seedlings were measured in each experiment. 


\section{Results}

Pathogenicity of the Bushland isolate and NA races $1,2,3$ and 4 of sunflower rust on Argentine, Australian and Canadian sunflower rust differential cultivars and sunflower germplasm lines are shown in Table 1. S 37-388, Guayacan INTA NAL and Impira INTA NAL were susceptible to NA races 1,2 and 3 . In addition, CM 29-3, CM 29-3-1-3-21, Morden 307-1 and Pergamino 71/538 were susceptible to NA race 2. while CM 90RR, F 164A and Impira INTA sel. 11 Castelar were susceptible to race 3

Table 1. Reaction of sunflower rust differential and sunflower germplasm lines to Bushland isolate and four North American (NA) races of sunflower rust (Puccinia helianthi)

\begin{tabular}{|c|c|c|c|c|c|}
\hline \multirow{3}{*}{$\begin{array}{l}\text { Sunflower rust } \\
\text { differentials } \\
\text { and germplasm } \\
\text { line }\end{array}$} & \multicolumn{5}{|c|}{ Sunflower rust } \\
\hline & \multirow{2}{*}{$\begin{array}{l}\text { Bushland } \\
\text { isolate }\end{array}$} & \multicolumn{4}{|c|}{ NA races } \\
\hline & & 1 & 2 & 3 & 4 \\
\hline \multicolumn{6}{|l|}{ Canadian-NDSF } \\
\hline S37-388 & $3,4^{\text {a) }}$ & 3,4 & 3,4 & 3,4 & $3,4^{\mathrm{a})}$ \\
\hline CM29-3 & 3,4 & 0 & 3,4 & 0,1 & 3,4 \\
\hline CM90RR & 3,4 & 0 & 0,1 & 3,4 & 3,4 \\
\hline \multicolumn{6}{|l|}{ Argentine-Antonelli } \\
\hline Impira INTA sel. 5 Castelar & 3,4 & 0 & 1,2 & 1,0 & 0,1 \\
\hline Impira INTA sel. 11 Castelar & 3,4 & 0 & 1,2 & 3,4 & 0,1 \\
\hline Pergamino $71 / 538$ & 3,4 & 0 & 3,4 & 0,1 & 1,2 \\
\hline Pergamino $78 / 287$ & 3,4 & 0 & 0 & 0 & 0,1 \\
\hline Saenz pena $74-1-2$ & 3,4 & 0 & 0 & 0 & 0 \\
\hline \multicolumn{6}{|l|}{ Argentine-Luciano and Luciani } \\
\hline Guayacan INTA NAL & 3,4 & 3,4 & 3,4 & 3,4 & 3,4 \\
\hline Impira INTA NAL & 3,4 & 3,4 & 3,4 & 3,4 & 3,4 \\
\hline F164A & 3,4 & 0 & 0,1 & 3,4 & 3,4 \\
\hline Morden 307-1 & 3,4 & 0 & 3,4 & 0 & 3,4 \\
\hline P386 & 3,4 & 0 & 0,1 & 0,1 & 0,1 \\
\hline \multicolumn{6}{|l|}{ Australian-Kochman } \\
\hline S $37-388$ & 3,4 & 3,4 & 3,4 & 3,4 & 3,4 \\
\hline CM 29-3-1-3-21 & 3,4 & 0 & 3,4 & 1,2 & 3,4 \\
\hline $953-88-3-1-54$ & 3,4 & 0 & 1,2 & 1,2 & 3,4 \\
\hline \multicolumn{6}{|l|}{ North Dakota-NDSF } \\
\hline $\mathrm{HA}-\mathrm{R} 1$ & 3,4 & 0 & 0 & 0 & 0 \\
\hline HA-R2 & 3,4 & 0 & 0 & 0 & 0 \\
\hline HA-R3 & 3,4 & 0 & 0 & 0 & 0 \\
\hline $\mathrm{HA}-\mathrm{R} 4$ & 3,4 & 0 & 0 & 0 & 0 \\
\hline HA-R5 & 3,4 & 0 & 0 & 0 & $0,1,2$ \\
\hline
\end{tabular}

a) 0-immune, no infection; 1-very resistant, hypersensitive reaction, pustules (broadest part) less than $0.2 \mathrm{~mm}$; 2-resistant, pustules 0.2 to $0.4 \mathrm{~mm} ; 3$-susceptible, pustules 0.4 to $0.6 \mathrm{~mm}$; 4-very susceptible, pustules larger than $0.6 \mathrm{~mm}$. 


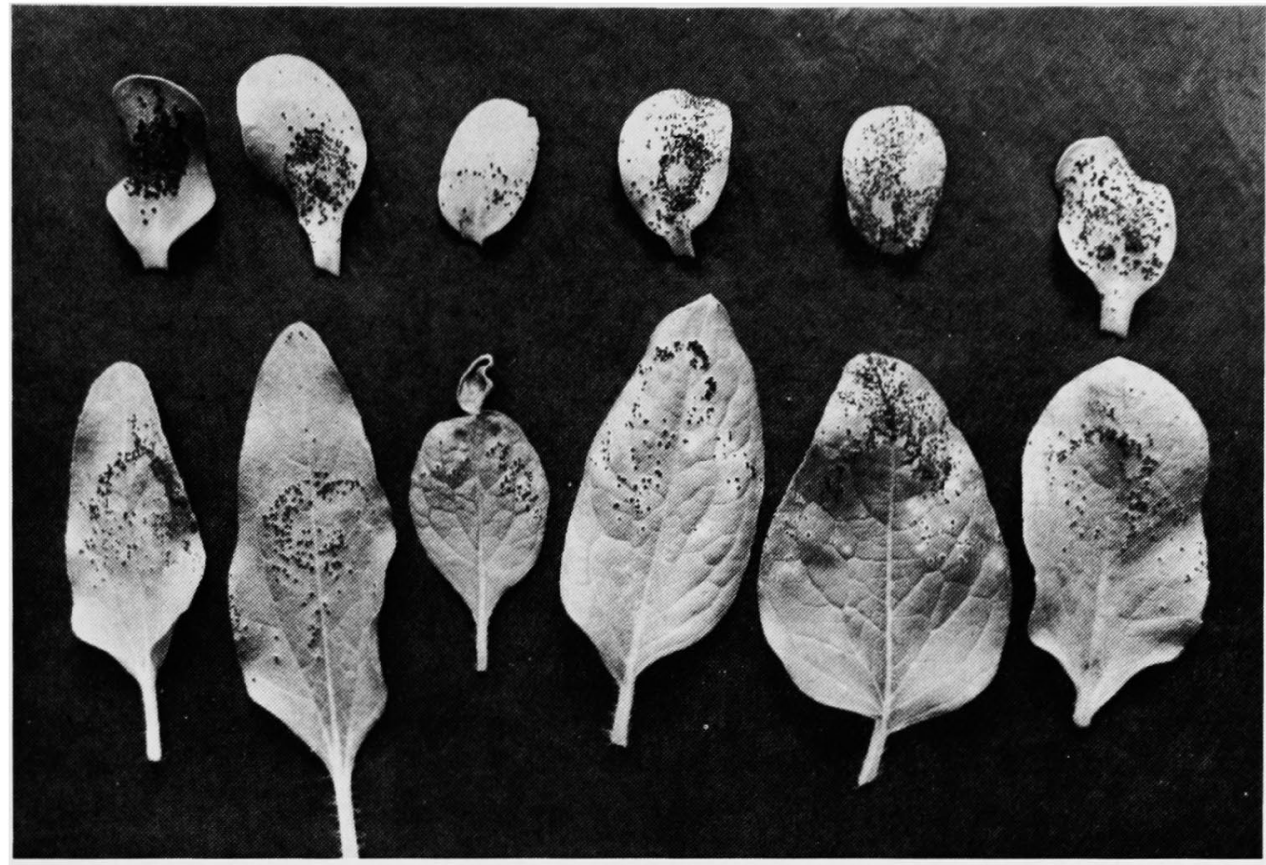

Fig. 2. Reaction of five sunflower germplasm lines and a universal suscept to Bushland isolate of sunflower rust. From left to right: HA-R 1, HA-R 2, HA-R 3, HA-R 4, HA-R 5 and S 37-388. S 37-388 (universal suscept) was susceptible but the five germplasm lines were resistant to the four standard North American races of sunflower rust.

(Table 1). The other sunflower rust differentials listed in Table 1 were resistant to NA races 1,2 and 3 .

The Bushland isolate was virulent on the five sunflower germplasm lines (Fig. 2) and all the sunflower rust differential cultivars and lines tested. NA race 4 was avirulent on P386, Impira INTA sel. 5 Castelar, Impira INTA sel. 11 Castelar, Pergamino 78/2 87 and Saenz pena 74-1-2 (Table 1). The sunflower germplasm lines HA-R1, HA-R2, HAR3 and HA-R4 were immune to NA race 4, while the Pergamino 71/538 and HA-R5 were resistant or very resistant to NA race 4 (Table 1 ).

The size of uredia produced by the Bushland isolate on P386, Pergamino 78/287, Saenz pena 74-1-2, HA-R1, HA-R2, HA-R3, HA-R4 and HA-R5 confirmed microscopically to reaction types 3 and 4 . The sizes of uredia produced by the Bushland isolate on other sunflower cultivars and lines mentioned in Table 1 were not measured microscopically.

\section{Discussion}

The Bushland isolate is different from NA Race 4 because HA-R1, HA-R2, HA-R 3, HA-R4, HA-R5, P 386, Pergamino 78/287, Saenz pena 74-1-2, Impira INTA sel. 5 Castelar, Impira INTA sel. 11 Castelar and Pergamino 71/538 were susceptible to the former but resistant to the latter. The Bushland isolate is also different from NA races 1,2 and 3 , since cultivars and lines resistant to NA races 1,2 and 3 were sus- 
ceptible to this Bushland isolate. The Bushland isolate is also virulent on CM 29-3-13-21 and 953-88-3-1-54, whereas races 1 and 3 from Australia have been reported to be avirulent ${ }^{3}$.

Pergamino 78/287 and Saenz pena 74-1-2 were resistant to Antonelli's 10 races of sunflower rust in Argentina (E. F. Antonelli, unpublished data). P 386 was also resistant to Luciano and Luciani's four races of sunflower rust in Argentina (A. Luciano and N. D. Luciani, unpublished data). Therefore, the Bushland isolate is also considered to be different from the ten rust races of Antonelli's and the four rust races of Luciano and Luciani's. It is assumed that the response of the selected differential lines to sunflower rust races is the same wherever tested, although the sunflower rust races from North America, Argentina, and Australia have never been compared on the sunflower rust differentials at the same location under the same conditions at the same time.

Sackston et al.5) reported three new races of sunflower rust from Argentina, based on the pathogenicity of the rust on three sunflower germplasm lines (B66-B100, MP 557 and 71-538). Sackston et al. tested their three races on neither Antonelli's nor on Luciano and Luciani's sunflower rust differentials and the three sunflower germplasm lines used by Sackston et al. were not available to other researchers because of company policy (W. E. Sackston, personal communication). One of Sackston et al.'s three races was virulent and two of the three were avirulent on sunflower line MP $577^{5)}$. One and nine of Antonelli's ten races were virulent and avirulent, respectively, on MP $557^{1,7}$. Thus, Sackston et al.'s three new races may belong to three of Antonelli's ten rust races.

It is concluded that the Bushland isolate is a new race of sunflower rust. This isolate has been deposited with American Type Culture Collection, Rockville, Maryland, USA (ATCC PR101), and also stored in liquid nitrogen at this laboratory.

\section{Literature cited}

1. Antonelli, E. F. (1985). In Proc. XI Int. Sunflower Conf., Vol. II. pp. 591-596.

2. Jabbar-Miah, M. A. and Sackston, W. E. (1967). Phytopathology $57: 1396-1397$.

3. Kockman, U. D. and Goulter, K. C. (1984). Australian Plant Pathol. $13: 3-4$.

4. Sackston, W. E. (1962). Canadian J. Bot. $40: 1449-1458$.

5. Sackston, W. E., de Romano, Bertero and Vasquez, A. (1985). In Proc. XI Int. Sunflower Conf., Vol. II. pp. 385-389.

6. Schneiter, A. A. and Miller, J. F. (1981). Crop Sci. $21: 901-903$.

7. Senetinez, A. C., Antonelli, E. F. and Luduenz, P. M. (1985). In Proc. XI Int. Sunflower Conf

8. Senetinez, A. C., Antonelli, E. F. and Luduenz, P. M. (1985). In Proc. XI Int. Sunflower Conf., Vol. II. pp. 591-596.

\section{和 文 摘 要}

Shaw-Ming YANG : ヒマワリさび病菌 (Puccinia helianthi) の1 新レース

1984年, テキサス州 Bushland に载培されているヒマワリから Puccinia helianthi のてれまでに未知の1 レースが分離された。本菌の北米の 4 レース、アルゼンチン産の Antonelli による10レース、および Luciano と Luciani による4レースのいずれに対しても抵抗性である本菌レース判別系統・品種はすへてて今回新しく

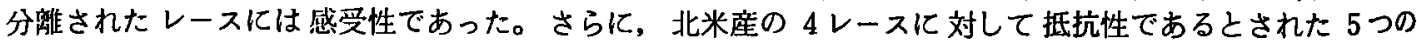
germplasma lines のヒマワリ、HA-R1，HA-R2，HA-R3，HA-R4 および HA-R5 むまた本レースに感受 性であった。これらの結果から，本分離株はヒマワリさび病菌の新レースであることが示された。 